\title{
STRATEGIC ANALYSIS TOOLS (SAT) APPLICATION AT SMALL \& MEDIUM-SIZED ENTERPRISES (SMES) IN THE NORTH AREA OF BUENOS AIRES ${ }^{1}$, ARGENTINA ${ }^{2}$
}

\author{
Leandro Adolfo Viltard \\ Pontificia Universidad Católica Argentina \\ Graduate School of Business, Facultad de Ciencias Económicas \\ Universidad de Palermo, Argentina \\ Universidad de San Isidro (USI), Argentina \\ Universidad del Pacífico, Ecuador \\ Universidad Nacional de La Pampa, Argentina \\ Universidad Nacional de Luján, Argentina \\ Universidad Nacional del Comahue, Argentina \\ E-mail: Iviltard@yahoo.com.ar
}

Submission: $18 / 09 / 2018$

Accept: 29/10/2018

\section{ABSTRACT}

This paper studies the nature and amplitude of Strategic Analysis Tools (SAT) application in SMEs located in emerging countries, specifically the North Area of Buenos Aires, Argentina (NABAA), where there are no formal studies on the subject. It is intended to understand their contribution to strategic options formulation and implementation. A survey to SMEs' owners/executives /managers in NABAA and interviews with specialists were applied, intending to analyze the use of these tools to facilitate the creation of strategic options, their support in assessing a competitive position and their promotion of superior performance. The results of this investigation developed that SAT and their related KPIs (Key Performance Indicators) should be considered in SMEs in order to improve strategy formulation and find better ways to implement it.

${ }^{1}$ This area is composed by the following counties: Vicente López, San Martín, San Fernando, Tigre (including Tigre, El Talar, San Fernando, Don Torcuato, San Isidro, Martínez, Boulogne, Munro, Villa Ballester, Ombú, San Martín, Churruca, El Palomar, Caseros y Santos Lugares).

2 This study was possible thanks to the collaboration of the following students of Universidad de San Isidro "Dr. Plácido Marín": Delfina Clusellas, delfi_clusellas@hotmail.com; Marianela González, gonzalezmar@hotmail.com.ar; Agustín Roes, agusroes@hotmail.com; and Romina Nasif Salum, roh.nasif@live.com.ar. 
INDEPENDENT JOURNAL OF MANAGEMENT \& PRODUCTION (IJM\&P)

http://www.ijmp.jor.br

v. 10, n. 3, May - June 2019

ISSN: 2236-269X

DOI: 10.14807/ijmp.v10i3.875

Their formalization - not leaving aside intuition- become a key issue as documenting this process appears vital when analyzing strategic options and performing better interrelations among different elements that may be identified. An improvement in strategic analysis may help also to have a better cohesion of company resources and achieve the established objectives. Unconsciousness, and cultural biases and barriers may explain their low usage rates. The final objective is to set aside from competition and build unattainable competitive advantages.

This is a qualitative investigation, and the research design is not experimental and transversal.

Keywords: Strategic Analysis Tools (SAT); Formulation; SME; Competitiveness; Value; Strategy.

\section{INTRODUCTION}

This study is complementary of prior ones made for Ecuador (PERALTA; VILTARD, 2016; PERALTA; VILTARD 2015A; PERALTA; VILTARD, 2015B), in which it was indicated, that consulting executives at SMEs do not opt for relevant tools to support their strategic decisions and/or when there is a need to outperform competition. In addition, (PERALTA; VILTARD, 2016; PERALTA; VILTARD, 2015B) assert that the Strategic Analysis Tools (SAT) that are analyzed in the theoretical framework of those studies ${ }^{3}$-and are approached in this one, too- are: Porter's five competitive forces, PEST Analysis, Swot Analysis, BCG Matrix, Ansoff's Matrix, The Value Chain Analysis (VCA), and The Activity System Mapping (ASM).

In this work, these tools are not analyzed in detail, but a summary of their main applications is introduced as follows:

${ }^{3}$ For further details on SAT theoretical framework, please refer to the prior works referenced. 


\begin{tabular}{|c|c|}
\hline Strategic Analysis tools & Applications \\
\hline Porter's five forces & $\begin{array}{l}\text { - Identifying relevant factors in the industry that ease reach } \\
\text { profitability and those that limit it. } \\
\text { - Benchmarking the competitive position with rivals }\end{array}$ \\
\hline PEST analysis & $\begin{array}{l}\text { - Assessing political and legal variables to identifying } \\
\text { opportunities, costs and constraints in the business environment } \\
\text { to make strategic choices. } \\
\text { - Evaluating the correlation between economic variables and } \\
\text { performance of firms in their respective sector. } \\
\text { - Taking advantage of socio-demographic to go in depth insights } \\
\text { over segmentation or micro-segmentation } \\
\text { - Assessing the impact of technology through the value chain }\end{array}$ \\
\hline SWOT & $\begin{array}{l}\text { - Applying methodology to measure competitiveness of the firm } \\
\text { compared with their competitors. }\end{array}$ \\
\hline Ansoff's Matrix & $\begin{array}{l}\text { - To outline generic actions to preserve, develop or conquer } \\
\text { markets }\end{array}$ \\
\hline VCA & $\begin{array}{l}\text { - Benchmarking the efficiency with competitors when using } \\
\text { resources } \\
\text { - Optimizing the execution of activities through scenarios of new } \\
\text { combination or suppression of them. }\end{array}$ \\
\hline ASM & $\begin{array}{l}\text { - Assessing complementarities or inconsistencies of activities } \\
\text { - Evaluating requirements to suppress, reinforce, patching or } \\
\text { creating new competencies and activities } \\
\text { - Evaluating the capability of firms to respond to changes in the } \\
\text { environment's configuration } \\
\text { - Optimizing the activity system through simulation of its } \\
\text { reconfiguration }\end{array}$ \\
\hline
\end{tabular}

Table 1: Applications of strategic analysis tools

Source: Álvarez Peralta and Viltard (2015b)

As a result, the general idea of this study refers to apply the same approach indifferent realities in order to find out if there exist other SAT usability patterns at SMEs.

But SMEs are very important for the economy of many countries, specifically Argentina, which is studied in this paper. In this sense, Martino (2018) asserts that SMEs have a huge impact in the Argentinean economy as they are "the engine, the growth and the roots of the country". Their relevance resides on the following specific matters: 8 out of 10 employees are hired in SMEs; half of what is billed belongs to these firms, being the ones where innovation investments are mainly done; and finally- they help to develop the geographic realities where they are settled. In addition, Martino, the CEO of HSBC, says that global banks must help these companies to be global and to have better and more technology, inserting them into the world and into the capital markets. Additionally, Álvarez Peralta and Viltard (2015b) highlight that competitiveness and strategic management constitute key elements to keep them sustainable in time. 
INDEPENDENT JOURNAL OF MANAGEMENT \& PRODUCTION (IJM\&P)

http://www.ijmp.jor.br

v. 10, n. 3, May - June 2019

ISSN: 2236-269X

DOI: 10.14807/ijmp.v10i3.875

Also, a strategic analysis process is needed in order to develop a business strategy, taking into consideration the business itself and the environment in which it operates. In this sense, Gartenstein (2018) suggests that it is needed to understand where you are in order to get where you want to go. That is the reason why SAT are used to map the current firm's position and its future direction and growth. The author insists that the future direction is composed of Strengths, Weaknesses, Opportunities and Threats SWOT analysis, expanded in (PERALTA; VILTARD, 2016A; PERALTA; VILTARD, $2016 b)$, and because many tools are subjective managers/executives need to be as honest and as at the point as possible.

Moreover, Lessard (2003) proposes that national and international firms must approach -at two different levels- the opportunities at each location: geographic scope and competitiveness. This analysis requires strategic thinking to develop an adequate framework and to be identified the course of action that is applicable to the organization. The author insists that in many cases -where tools are not necessarily valid- intuition or a non-formalized assessment may be applicable.

Finally, it was evidenced -in the sample of 40 SMEs analyzed and in the 6 interviews made with specialists- that SAT are barely utilized and with no formalization.

The field analysis was focused on inquiring if there were used other instruments or specific actions in order to improve competitiveness, and if there may be found other approaches that may challenge conventional theories. It was found that these firms are not prone to allocate resources to take advantage of these tools, missing important elements or valuable connections among them.

As a result, the hypothesis of this paper states that SAT application and their formalization allow management's teams to identify discussion areas that will lead to a better competitive positioning. In addition, they are important to extract insights from inside/outside information.

The objective of this study is to verify the level of awareness regarding SAT applicability and solvency in NABAA; specifically, its ability to create better 
INDEPENDENT JOURNAL OF MANAGEMENT \& PRODUCTION (IJM\&P)

http://www.ijmp.jor.br

v. 10, n. 3, May - June 2019

ISSN: 2236-269X

DOI: 10.14807/ijmp.v10i3.875

strategic options and relevant choices in the competitive and organizational arenas.

\subsection{Design: Methodology and analysis}

This is an explorative and descriptive study, with a qualitative methodology. The research design is not experimental and -among themtransversal.

It was performed in Buenos Aires, Argentina, and the information was gathered at a moment in time (February-September, 2018).

The analysis unit corresponds to SMEs settled in the North area of Buenos Aires, Argentina (NABAA).

Data collection involved the following tasks: a) instrument' configuration, b) instrument' application, and c) data available analysis.

The samples were intentional, directed and not probabilistic, and -as a qualitative study- their sizes do not imply to arrive to adequate conclusions.

As it is explained afterwards, this investigation is based on a field study composed by:

- A survey sent to 200 SMEs' owners/executives/managers of the NABAA. The final sample is composed by 40 positive replies $(20 \%$ of the total forms sent), that although they may be considered a small quantity of firms participating in the survey, it is understood that this low reply level was because these firms were not known to the researchers and also because their executives were very sensible to give information on their activities, as it was said by different specialists during our interviews. Anyway and to better support this investigation, the sample was complemented with interviews to different specialists who provided the information that is shown in this study.

As a qualitative research and with the purpose to select a not statistical sample, the focus was on studying firms that were representative of their industrial sectors, in accordance to what it was known in the area and what different articles and magazines referred. 
INDEPENDENT JOURNAL OF MANAGEMENT \& PRODUCTION (IJM\&P)

http://www.ijmp.jor.br

v. 10, n. 3, May - June 2019

ISSN: 2236-269X

DOI: 10.14807/ijmp.v10i3.875

These 40 firms had a local ownership and they included a diverse number of industrial sectors, as it is shown in the following Table:

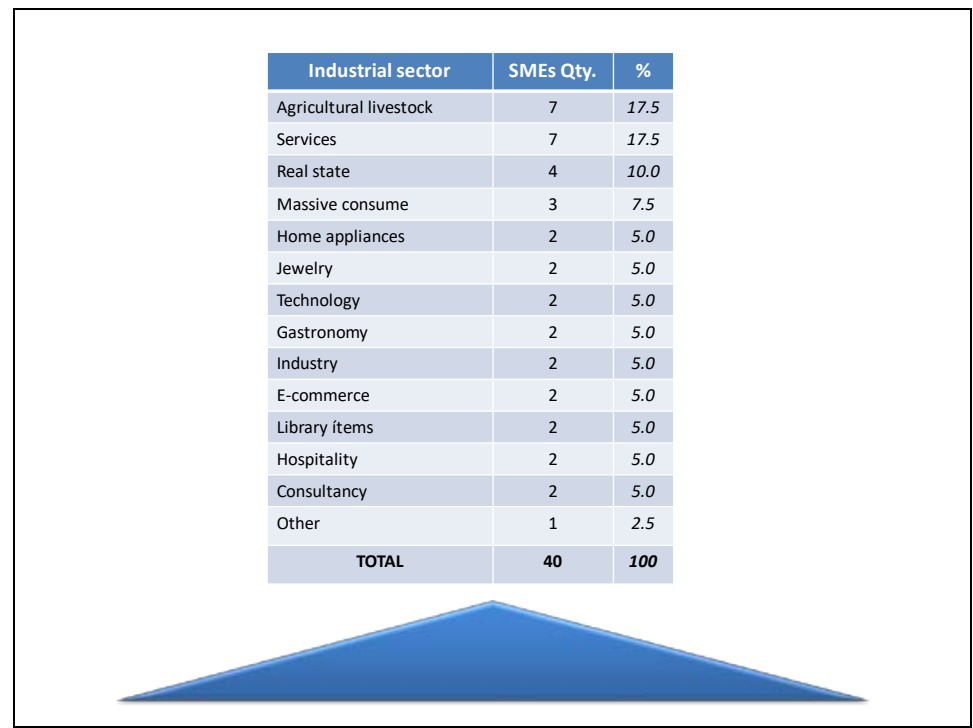

Table 2: SMEs sample's industrial sectors Source: Own

Additionally, most of these companies ${ }^{4}$ did not exceed one hundred employees, as it is shown in the following Table:



The survey had 23 closed questions and 1 open (final comments). It also included the objective, and some definitions/clarifications to help on a better

${ }^{4}$ Because of confidential matters the firm's executives/owners were not able to provide the revenue of these companies. 
INDEPENDENT JOURNAL OF MANAGEMENT \& PRODUCTION (IJM\&P)

http://www.ijmp.jor.br

v. 10, n. 3, May - June 2019

ISSN: 2236-269X

DOI: 10.14807/ijmp.v10i3.875

comprehension of the research and to enhance the probability in obtaining replies the more accurate as possible.

- Interviews were done with specialists and firm's owners/executives /managers in order to expand and complement the investigation, and to better support the survey results. The interviews were held in their offices in order to allow the interviewees to be comfortable in the place they chose, with the following specialists:

o Dr. Claudio O. Méndez, President of the Professional Council of Economic Sciences-San Isidro Delegation (PCES). This institution covered the studied area, and -in addition- he is the owner of a firm that offers consulting services to SMEs (organization, taxes and accounting).

The interview was performed in the PCES' offices on 07/17/2018.

The PCES has organized their own sectors of interest in which they had special teams created for assessing them. The classification of sectors used in this study included a similar criteria to the one used by this organization.

o Isidoro Barrera, entrepreneur and owner of Nala Media, firm that offers consulting and support services for companies (services, management advice, accounting, brands and patents, advertising and design). Previously, he worked for IBM Argentina and a private own consultancy firm.

The interview was carried out through Skype on 07/20/2018.

o Federico Fernández, Miljugadas.com CEO, gaming company.

The interview was held on 08/01/2018 in his office.

o Horacio Etchegoyen, owner of San Doménico S.A., firm that is focused on agricultural livestock.

The interview was kept on 09/07/2018 by telephone. 
o José Ganora, Human Talent Manager at Educar S.R.L., company that is focused on education, and advisory services, management and business management. Interview held on 09/12/2018.

o Carlos Oubina, accountant at DBG S.R.L., firm that offers storage and warehouse services. Interview carried out on 09/18/2018.

In this field study, it was also targeted to know complementary objectives aimed at keeping or generating sustainable competitive advantage.

\subsection{Research limitations/clarifications}

- This is not a bibliographical investigation and it complements prior researches made on the matter for SMEs of Quito, Ecuador (PERALTA; VILTARD, 2015A, 2015B, 2016a, 2016b). That is why it is a field study which aims to analyze a different location -the NABAA- to see if diverse results may arise. As a result, this paper is concentrated on the results showed by the reply to the survey, applied to firm's owners/executives/managers established in the studied area, and on 6 interviews held with specialists.

- As the objective of the survey was to have as many answers as possible, the final sample of 40 cases is the best representation of the work done and of the firms that are settled in the NABAA.

- The interviews with specialists (6 in total) were the ones that were retained to be useful in order to complement the survey.

- Conclusions of this study are based on the information gathered. As a qualitative study, results cannot be generalized but they can be used to take decisions on the matter. Basically, they are useful to avoid misconceptions and biases that may prevent managers of using these instruments properly.

\subsection{Findings}

As in prior studies, in SMEs it was found a lack of consciousness about potential benefits of SAT application and a majority of owners/executives /managers that are tied up to cultural factors/biases. Specifically, they were 
INDEPENDENT JOURNAL OF MANAGEMENT \& PRODUCTION (IJM\&P)

http://www.ijmp.jor.br

v. 10, n. 3, May - June 2019

ISSN: 2236-269X

DOI: 10.14807/ijmp.v10i3.875

immerse in a daily-operation solving oriented mind frame that may cause a general low utilization rate of the analyzed tools in this firms' category.

Also, it was found that consideration of owners/managers/executives of value perception when using these tools could contribute to either assessing their competitive position or creating their own approaches to outperform competitors.

\subsection{Originality and Value}

As there are no other known studies of this matter in NABAA, this research may be considered a first attempt to explore SAT utilization in this geographic area. Results may help to develop a better competitive perspective and positioning of the SMEs located in NABAA.

\section{SURVEY TO SMES' OWNERS/EXECUTIVES/MANAGERS}

\subsection{The survey approach}

As it was said before, the analysis unit corresponds to SMEs located in NABAA included in the sample.

The reply unit was the owners/executives/managers to whom the survey was directed.

The survey included SMEs with some characteristics in common: eager to grow, little access to credit facilities, flexibility to adapt to changes and with some communication difficulties with final customers.

The questions that were considered in the sample were mainly addressed to know: a) if SAT was used and which functions were in charge of this activity; b) how were evaluated competitors' actions; c) produce a list of SAT that were utilized and if there was any particular order of application, and d) if there was any impact/improvement on the firm after SAT application.

\subsection{The survey results}

The general results of the 40 replies obtained can be summarized as follows:

- The whole set of firms' owners/executives/managers included in the sample understood that SAT utilization could reinforce their competitive position, but $73 \%$ did not use these instruments, giving the following 
reasons: small organization, urgencies and scarce objectives/business direction delimitation. As a result, only the $27 \%$ utilized some of these tools.

- Where SAT were applied:

o The following functions participated: General Management (61\%), Marketing (13\%), and Finance, Sales and Production the rest.

o To formulate strategy, these tools were mostly utilized: SWOT analysis (40\%), PEST Analysis (17\%), Product-Market Matrix $(13 \%)$ and Value Chain Analysis (10\%).

o The order in which these tools were utilized was: SWOT Analysis (35\%), PEST Analysis (20\%), Value Chain Analysis (20\%), Product-Market Matrix (10\%) and Growth-Market Share Participation Matrix (10\%).

- The most important external aspects that influenced in their firms were economic (52\%), politic (19\%), social (18\%) and technological (8\%).

- The strategy was formulated and reviewed each six months (53\%), once a year (40\%) and in variable terms (7\%).

- The resources that were mostly utilized to evaluate competition included: connections with clients and vendors; sales force; consultants; employees that worked before for competitors; and specialized reports.

- The most important areas of excellence in which the companies invested in order to maintain their competitive position were: Technology (27\%), Production (23\%), Design (17\%) and Marketing (17\%).

- A total of $80 \%$ of the firms didn't use key indicators which showed their competitive position in their markets. The $20 \%$ of the firms that used these metrics mostly used sales volumes; sales prices and prices variations; quality and volume of the most important competitors in the most relevant customers; and revenue per customer.

- After the implementation of a strategy formulation process in the last years, indicators showed improvements in less than $10 \%$ (29\% of the cases), from $10 \%$ to $20 \%(29 \%)$, from $21 \%$ to $30 \%$ (24\%), from $31 \%$ and $40 \%(14 \%)$, and the rest (4\%) in more than $41 \%$. 
- In order to increase the gap on prices, there were mostly used product differentiation (33\% of the cases), scale (17\%), activities reconfiguration (13\%) and influence on customer's bargaining power (10\%). A total of $10 \%$ didn't do anything on the matter.

- In the last three years and in the $67 \%$ of the cases, it was possible to implement improvements in processes, marketing, and product and service design.

- Firms that participated in the sample proposed either radical or incremental changes in their business. In front of radical changes and in the $63 \%$ of the cases, they had a positive impact, from $10 \%$ to $40 \%$. A total of $14 \%$ had no impact on their operations.

- SMEs that did not implement improvements pointed out that it was because of costs and market drops.

Some of the most relevant general comments that were provided by the owners/executives/managers who participated in the survey are summarized, as follows:

\subsection{Negative/Neutral comments}

- Although these tools are important to have a better understanding and control of our business, Argentina is a difficult country as a short term view is installed. I suggest using these tools twice a year.

- In SMEs it is more difficult to perform a thorough and continued strategic plan as their structures are not stabilized in each area/process.

- In my opinion, it is extremely important to use these tools but they depend on available resources and on means to achieve objectives.

- We have a small firm. That is why our strategy is the result of our experiences in the last years without great statements.

- Volume drops do not help to think about strategy.

- We do not use these tools.

\subsection{Positive comments}

- As we are facing dynamic markets, SAT are important to take advantage of opportunities. This is an exercise that should be done every 6 months. We are a small firm; fortunately we perform meetings every week to be 
updated on changes, costs, customers' preferences, possibilities of expansion and new distribution channels.

- In SMEs, it is relevant to set up objectives and strategies to achieve them.

- Strategies are present in everything we do; basically, when products, customers and vendors are searched.

- To use different tools becomes a huge contribution to company growth. We should utilize them more regularly in order to widen our points of view and make the necessary adjustments.

- Very helpful to have a better differentiation from competition, mostly because we are facing a very voracious rivalry in our market.

- As markets are saturated and very dynamic, strategies are helpful in order to make the necessary company's transformations. Addtionally, periodic controls and reviews are key elements to correct the course of action.

- As the health market is going through a profound transformation, strategies are necessary to compete and add new customers. In this context, excellence is a must and our objective is to improve the performance of our professionals through scholarships, training, technology and better tools.

- Apart from these tools, the Commercial area must have adequate skills in order to react to economic changes. The exchange rate devaluation that we went through these last weeks, obliged to review our short and medium term strategies.

\section{INTERVIEWS WITH SPECIALISTS}

The outcomes of the survey were complemented with interviews with specialists who are listed in the Introduction of this study. In the following paragraphs are summarized the results of these meetings:

- As SMEs are untrained, SAT are not commonly known and used.

- Some firms are utilizing one or two tools. For example, one of them was using Value Chain Analysis and Growth Matrix (Ansoff); another PEST analysis, and a third one the SWAT analysis. 
- The main benefit perceived of using SAT was to know where the firm stands in connection with the market, objectives and goals in order to understand the business from a more strategic vision and perform processes with higher efficiency levels. An adequate set of Key Performance Indicators (KPI) may help to improve the different company areas.

- Many SME are focused on accounting in order to reduce the tax burden.

- Claudio Méndez referred that SAT are in practice intuitively -not formallyin every SME of 20 to 80 employees where resources must be coordinated and decisions are made. The SAT mostly used and in the following sequence are: 1) FODA Analysis, 2) PEST Analysis, 3) Value Chain Analysis, 4) Porter's Five Competitive Forces and 5) Growth Matrix (Ansoff). In the smallest firms SAT are under strict owner's utilization, and in bigger ones the intermediate management is who apply them but under strict owner's supervision. After their utilization there are seen capabilities' improvements and better firm's positioning.

\section{CONCLUSIONS}

Although some authors remark that some tools are not necessarily valid and a non-formalized approach may be applicable, it is adverted that SAT are barely and, at the most, intuitively applied in SMEs. Its formalization may help to deepen the analysis, and perform better interrelationships among different and complex internal and external variables where the businesses are struggling. In fact and in the survey, there were identified important external factors influencing company's environment such as economic, politic, social and technological.

Also, it was recognized SAT ability to create better strategic options and relevant choices in the competitive and organizational arenas but, because of different reasons -such as Argentina's short term view, costs, market drops and daily urgencies- were not adequately considered. Expanding the idea of strategic options creation, the survey revealed that:

- Strategy had been formulated and reviewed basically each six or twelve months. 
- The most common resources used to evaluate competition had been the connection with clients and vendors, sales force, consultants, employees that worked before for competitors and specialized reports.

- The most important areas of excellence where the firms had invested were technology, production, design and marketing

Moreover and where SAT had been applied, the main functions that used them were General Management, Marketing, Finance, Sales and Production. Also, the most utilized to formulate strategy and the order in which they were used was: 1) SWOT Analysis, 2) PEST Analysis, 3) Value Chain Analysis, 4) Product-Market Matrix and 5) Growth-Market Share Participation Matrix.

The field analysis was pursued to know if there were utilized other tools or specific actions to improve competitiveness or if there were found other approaches that could challenge conventional theories. For instance, some surveyed and interviewees pointed out the lack of resources in SMEs, but when speaking about strategic options and access to additional resources it didn't come out the importance of strategic alliances or if they were working on building additional capabilities in other ways. In addition and in more demanding markets like health, it brought out that a few SAT were in practice, showing that it seemed that their applicability only depended on SMEs' external and not on internal factors, such as growth needs, or access to new capabilities and skills.

Basically, it was found that these firms were not prone to allocate resources to take advantage of these tools, missing important elements or valuable interconnections among them.

Since this paper aims to approach SAT applicability and its formalization in order to identify review areas that will lead to a better competitive positioning, it is remarked the importance of extracting insights from inside/outside information.

In this sense, it was found that $80 \%$ of the surveyed firms were not using KPIs that showed their competitive position in their markets. The ones that utilized these metrics were mostly using sales volumes; sales prices and prices 
INDEPENDENT JOURNAL OF MANAGEMENT \& PRODUCTION (IJM\&P)

http://www.ijmp.jor.br

v. 10, n. 3, May - June 2019

ISSN: 2236-269X

DOI: 10.14807/ijmp.v10i3.875

variations; quality and volume of the most important competitors in the most relevant customers; and revenue per customer. It is highlighted that after the implementation of a strategy formulation process, indicators showed improvements -which didn't exceed 40\%- in most of the cases (96\%).

Out of what authors and the field analysis show, there are remarked some benefits of SAT utilization: a) better business positioning through understanding of where it stands, the economic changes that are faced and approaching business from a more strategic vision; b) take advantage of opportunities and establish a better differentiation from competition, c) set up clear objectives and strategies, d) contribution to firm transformation and growth; e) people's performance improvement and processes direction to higher efficiency levels; f) company improvement and follow-up through an adequate set of KPIs.

As in prior studies, it was found evidence that SMEs' owners/executives/managers had a lack of consciousness about potential benefits of SAT application, and the majority of them were bound to cultural factors and biases. In this sense, the survey showed impacting elements: a) in Argentina, a short-term view and a daily-operation solving oriented mind frame were common; b) there were no firms' stable structures; c) markets were being mainly approached with available resources; d) strategies had been the result of experience, and e) volume instability was not helping to make a better reflection on strategy.

Finally, SAT and their related KPIs should be considered in SMEs in order to improve strategy formulation and find better ways to implement it. Their formalization -not leaving aside intuition- become a key issue as documenting this process appears vital when analyzing strategic options and performing better interrelations among different elements that may be identified. An improvement in strategic analysis may help also to have a better cohesion of company resources and achieve the established objectives.

Unconsciousness, and cultural biases and barriers may explain their low usage rates. The final purpose is to set aside from competition and build unattainable competitive advantages. 
INDEPENDENT JOURNAL OF MANAGEMENT \& PRODUCTION (IJM\&P)

http://www.ijmp.jor.br

v. 10, n. 3, May - June 2019

ISSN: 2236-269X

DOI: 10.14807/ijmp.v10i3.875

It must be highlighted that, as a consequence of what is stated in these conclusions, the hypothesis of this study was corroborated and the objective.

\section{REFERENCES}

ÁLVAREZ PERALTA, D. H.; VILTARD, L. A. (2016a) Herramientas estratégicas para la Pequeña y Mediana empresa (Pyme). El caso de las firmas de Quito, Ecuador (Strategic tolos for SMEs, the case of Quito's firms, Ecuador), B. S. Lab., Avellino, Italy.

ÁlVAREZ PERALTA, D. H.; VILTARD, L. A. (2016b) Herramientas de análisis estratégico. Una propuestas para la Pequeña y Mediana Empresa, Palermo Business Review, n. 14.

ÁlVAREZ PERALTA, D. H.; VILTARD, L. A. (2015a) Strategic Analysis Tools Application at SMEs in Ecuador, Independent Journal of Management \& Production (IJM\&P), v. 6, n. 4, ISSN: 2236-269X.

ÁlVAREZ PERALTA, D. H.; VILTARD, L. A. (2015b) Simple Strategic Analysis Tools at SMEs in Ecuador, Independent Journal of Management \& Production (IJM\&P), v. 6, n. 2, ISSN: 2236-269X.

GARTENSTEIN, D. (2018) How to Write a Strategic Analysis for Business Organizations, Small Business - Chron.com, retrieved from http://smallbusiness.chron.com/write-strategic-analysis-business-organizations-

89.html, on 06/20/2018.

LESSARD, D. (2003) Frameworks for Global Strategic Analysis, Senate Hall Academic Publishing (MIT), v. 1, n. 1.

MARTINO, G. (2018) Las pymes son el motor de la Argentina, Diario La Nación 03/25/2018, retrieved from ttps://www.lanacion.com.ar/2119790-las-pymes-son-elmotor-de-la-argentina, on 06/18/2018.

VILTARD, L. A. (2017) Strategic mistakes (avoidable): The topicality of Michael's Porter generic strategies, Independent Journal of Management \& Production (IJM\&P), v. 8, n. 2, ISSN: 2236-269X.

VILTARD, L. A. (2016) Unlimited: Blurred limits in a borderless world, Independent Journal of Management \& Production (IJM\&P), v. 7, n. 2, ISSN: 2236-269X. 